\title{
Laboratory study of subjective perceptions to low temperature heating systems with exhaust ventilation in Nordic countries
}

\author{
Jin, Quan; Simone, Angela; Olesen, Bjarne W.; Holmberg, Sture K.M.; Bourdakis, Eleftherios
}

Published in:

Science and Technology for the Built Environment

Link to article, DOI:

$10.1080 / 23744731.2017 .1251266$

Publication date:

2017

Document Version

Peer reviewed version

Link back to DTU Orbit

Citation (APA):

Jin, Q., Simone, A., Olesen, B. W., Holmberg, S. K. M., \& Bourdakis, E. (2017). Laboratory study of subjective perceptions to low temperature heating systems with exhaust ventilation in Nordic countries. Science and Technology for the Built Environment, 23, 457-468. https://doi.org/10.1080/237444731.2017.1251266

\section{General rights}

Copyright and moral rights for the publications made accessible in the public portal are retained by the authors and/or other copyright owners and it is a condition of accessing publications that users recognise and abide by the legal requirements associated with these rights.

- Users may download and print one copy of any publication from the public portal for the purpose of private study or research.

- You may not further distribute the material or use it for any profit-making activity or commercial gain

- You may freely distribute the URL identifying the publication in the public portal 


\section{ACCEPTED MANUSCRIPT}

\section{Laboratory study of subjective perceptions to low temperature heating systems with exhaust ventilation in Nordic countries}

Quan Jin ${ }^{1,2, *}$, Angela Simone ${ }^{3}$, Bjarne W. Olesen ${ }^{3}$, Sture K. M. Holmberg ${ }^{1}$, and Eleftherios Bourdakis $^{3}$

${ }^{1}$ Civil and Architectural Engineering, KTH Royal Institute of Technology, Stockholm, Sweden ${ }^{2}$ Civil and Environmental Engineering, Chalmers University of Technology, Gothenburg, SE 412 96, Sweden

${ }^{3}$ International Centre for Indoor Environment and Energy, Technical University of Denmark, Copenhagen, Denmark

*Corresponding author e-mail: quan.jin@chalmers.se

Quan Jin, PhD, Associate Member ASHRAE, is a Postdoctoral Researcher. Angela Simone, PhD, is a Researcher. Bjarne W. Olesen, PhD, Member ASHRAE, is a Professor. Sture K. M. Holmberg, PhD, is a Professor. Eleftherios Bourdakis is a PhD Candidate.

Given the global trends of rising energy demand and the increasing utilization of low-grade renewable energy, low temperature heating systems can play key roles in improving building energy efficiency while providing a comfortable indoor environment. To meet the need to retrofit existing buildings in Nordic countries for greater energy efficiency, this study focused on human subjects' thermal sensation, thermal comfort, thermal acceptability, draft acceptability and perceived air quality when three low temperature heating systems were used: conventional radiator, ventilation radiator or floor heating with exhaust ventilation. Human subject tests were carried out in the climate chamber at the Technical University of Denmark. In total, 24 human subjects, 12 females and 12 males participated in the tests during the winter season. The results 


\section{ACCEPTED MANUSCRIPT}

show that no significant differences in thermal sensation and thermal comfort between the three heating systems. Ventilation radiator promised a comfortable indoor environment with a decreased water supply temperature and floor heating with exhaust ventilation can provide a basic thermal comfort level. Thermal acceptability and draft acceptability show variations in different heating systems. Gender has significant influences on thermal sensation, draft acceptability and preference of clo values. Personal thermal preference is observed between male and female. The male prefer to dress lighter than the female but both can get the same thermal comfort level. It is concluded that low temperature heating systems using exhaust air ventilation are a potentially solution when buildings are being retrofitted for improved energy efficiency and comfort of the occupants.

Key words

thermal comfort; perceived air quality; low temperature heating; ventilation radiator; floor heating. 


\section{ACCEPTED MANUSCRIPT}

\section{Abbreviations}

CR conventional radiator

VR ventilation radiator

FH floor heating

Nomenclature

$T_{\mathrm{o}} \quad$ operative temperature, ${ }^{\circ} \mathrm{C}$

$T_{\mathrm{a}} \quad$ air temperature, ${ }^{\circ} \mathrm{C}$

$T_{s} \quad$ air supply temperature, ${ }^{\circ} \mathrm{C}$

$T_{\text {surface }} \quad$ window's surface temperature, ${ }^{\circ} \mathrm{C}$

$T_{\text {outside }} \quad$ outdoor air temperature, ${ }^{\circ} \mathrm{C}$

$T_{r} \quad$ radiator's surface temperature, ${ }^{\circ} \mathrm{C}$

$T_{f} \quad$ floor's surface temperature, ${ }^{\circ} \mathrm{C}$

$\mathrm{U}$ heat transfer coefficient of window, $\mathrm{W} /\left(\mathrm{m}^{2} \mathrm{~K}\right)$

$h \quad$ heat transfer coefficient of surface, $\mathrm{W} /\left(\mathrm{m}^{2} \mathrm{~K}\right)$

\section{Introduction}

Retrofitting existing buildings to improve energy efficiency has a significant role to play in reaching the EU Horizon 2020 target for decreasing green gas emission. The renovation of existing buildings represents more than $17 \%$ of the primary energy savings potential of the EU up to 2050 (Tobias et al. 2012). This gives the chance to reduce energy demand and utilize lowgrade thermal source and renewable energy such as geothermal, waste heat, solar radiation, and etc., which can supply low temperature piped water of $50-55^{\circ} \mathrm{C}$ (Brand et al. 2012) into building 


\section{ACCEPTED MANUSCRIPT}

for space heating. Concerning both the building side and the source side, low temperature heating systems are to be implemented during the building retrofit process and in new buildings.

In Nordic countries, water based radiator and floor heating are commonly used for space heating. Traditionally, radiators are operated with high temperature water supply $\left(75-90{ }^{\circ} \mathrm{C}\right)$ (Boerstra 2000). In comparison, low temperature ventilation-radiators operate between $45-35{ }^{\circ} \mathrm{C}$ and are more energy efficient in comparison to the conventional radiator (Boerstra and Holmberg 2009; Ploskić and Holmberg 2013; Maivel and Kurnitski 2014). Because of the enhanced convection heat transfer in the radiator, heating efficiency is improved significantly. This was comprehensively studied and proved by both simulation and laboratory testing (Ploskić and Holmberg 2013; Maivel and Holmberg 2013). In addition to the low temperature heating systems of floor, wall and ceiling radiant systems (Babiak et al. 2013), the ventilation-radiator is a promising system for buildings being retrofitted.

From the occupants' point of view, comfort of the indoor environment should never been sacrificed for other priorities. The majority of Swedish buildings have since the mid-1900s been equipped with exhaust ventilation systems, either with or without heat recovery, where ventilation air was brought in directly from the outdoors through the building wall (Myhren 2011). In comparison with balanced ventilation or supply and exhaust ventilation, the proportion of exhaust ventilation has been around 60\% since 2001 (Svensk Fjärrvärme AB 2009). Some studies have concluded that fewer health related problems were reported in buildings with exhaust ventilation (Wargocki et al. 2002).

However, if the appropriate assessment is not made before construction begins and issues that may affect thermal comfort are not identified home energy retrofit activities with low 


\section{ACCEPTED MANUSCRIPT}

temperature heating systems might also negatively affect thermal comfort and perceived air quality. Indoor surveys of apartment buildings located in the north and central regions of Sweden found that $85 \%$ of the buildings were constructed before 1975 (Zalejska-Jonsson and Wilhelmsson 2013). The most often observed problem was too low indoor temperature. Moreover, $45 \%$ of occupants reported thermal comfort problems on too low or unstable temperatures, and about $40 \%$ of occupant responses also reported stuffy air and $30 \%$ reported smelly air. Bluyssen’s study (Bluyssen 2000) surveyed 26 apartments, during autumn and winter, to gather data pertaining to future building renovation work. The 403 occupant responses highlighted thermal comfort issues as the main problem including draft and air quality. Stuffy and bad smelling indoor air was also observed due to insufficient ventilation. Also, exhaust ventilation systems have the potential to generate cold drafts near the window. Traditionally, radiators are installed under the window to counteract the down draft and make occupants feel comfortable. In low temperature water supply systems, the surface temperature of radiator is lower than conventional radiator. As a result, there's greater potential for occupants to experience more cold draft near the window. Floor heating system shares this potential for drafts.

In the previous study, thermal comfort was checked by computational fluid dynamics simulation under the arrangements of ventilation radiator and inlet of cold air fitted between radiator panels, and conventional radiator and inlet of cold air above the window (Myhren and Holmber 2009). The simulated results showed that the comfort temperature was $21.0{ }^{\circ} \mathrm{C}$ at $1.1 \mathrm{~m}$ above floor level in the room centre, but it was more favourable and stable thermal climate with ventilation radiator system under the given conditions in comparison to the conventional radiator system. There were small temperature variations because of a pre-heated cold air and a large 


\section{ACCEPTED MANUSCRIPT}

temperature differences in the area close to the window wall under conventional radiator system. In an early study, radiator system and floor heating system were both tested in a well-insulated test room (Olesen et al. 1980). The air infiltration was simulated around the window. When the temperature level in the room provided thermal neutrality, there would be a small likelihood of local discomfort. Under floor heating system, there was a risk of mean air velocity higher than $0.1 \mathrm{~m} / \mathrm{s}$ along the floor when the down-draft along the window was not counteracted by an upward convection. However, no subjective study was further carried out to check the actual thermal comfort with the given conditions. In addition, local discomfort or local thermal sensation and gender differences were not checked. Local thermal sensation has been proved to be a significant influence on overall thermal sensation and local discomfort may cause an overall discomfort perception (Arens et al. 2006; Jin et al. 2011). Also, a growing number of studies have found significant differences of thermal comfort between genders (Fanger 1970; Karjalainen 2012). The perceived indoor environment under low temperature water based radiators in which the water is generally below $45^{\circ} \mathrm{C}$, has not been adequately studied. Hence, the relative thermal comfort of ventilation radiators or floor heating combined with exhaust ventilation must be ascertained before choosing the type of low temperature heating systems in a building retrofit.

Given the high cost of replacing exhaust air ventilation, in Sweden, the question of whether thermal comfort condition can still be maintained or improved by different low temperature heating systems is uncertain. The present study focused on the outcomes of human subject assessments to compare indoor environments equipped with three different low temperature heating systems: conventional radiator, ventilation radiator and floor heating with exhaust 


\section{ACCEPTED MANUSCRIPT}

ventilation. The typical parameters of buildings built before 2000 was defined the general context of the testing. The work addressed the possibilities and limitations in using low temperature heating systems in building retrofits.

\section{Methods}

\section{Indoor environment chamber}

The study was carried out in an indoor environmental chamber at the International Centre for Indoor Environment and Energy (ICIEE) at the Technical University of Denmark (DTU) (Toftum 2004). The chamber has a net internal dimension $(l \times b \times h)$ of $4.2 \mathrm{~m} \times 4.0 \times 2.7 \mathrm{~m}$. The background sound pressure level is less than $35 \mathrm{~dB}$. All the materials used in the chamber have low sensory emission characteristics (Toftum 2004). A uniform lighting was provided by high frequency fluorescent lamps. Figure 1 shows the setup of different heating systems installed in the chamber: the conventional radiator under the window, the ventilation radiator under the window, the floor heating over the chamber floor.

All the walls were thermally insulated and the heat transmission coefficient was $0.25 \mathrm{~W} /$ $(\mathrm{m} 2 \mathrm{~K})$. The window's heat transfer coefficient was equivalent to $2.1 \mathrm{~W} /(\mathrm{m} 2 \mathrm{~K})$ which is typical in buildings built between 1975 and 2000 in Sweden and Finland. The window was simulated by cooling panels positioned in the front wall with an area of $6.4 \mathrm{~m} 2$. The bottom part was thermally insulated by polystyrene board.

The chamber was set up to mimic a living room in a typical residential unit with one big table, two chairs, two computers, two shelf and some decorated paintings. They were arranged in a symmetrical layout with two persons sitting inside the occupied zone as shown in Fig. 2. 


\section{ACCEPTED MANUSCRIPT}

\section{Heat emitters}

There were three heating emitters installed inside the chamber, including a conventional radiator $(\mathrm{CR})$, a ventilation radiator $(\mathrm{VR})$ and floor heating $(\mathrm{FH})$. CR and VR were installed below the simulated window and positioned on the central line of the chamber. The dimensions $(\mathrm{l} \times \mathrm{h})$ for $\mathrm{CR}$ and VR were $500 \mathrm{~mm} \times 1200 \mathrm{~mm}$. CR is a two-panel radiator where one panel has convection fins. VR is a two-panel radiator where two panels have convection fins. In contrasts to $\mathrm{CR}$, the ventilation radiator combines the conventional radiator with an air-supply ventilation diffuser. The supplied air is conducted to the channel between the two panels of the conventional double pane radiator as preheated and then enters into the indoor environment. FH was already installed over the original chamber floor and separated from it by a layer of insulation board (Causone et al. 2010). The heating pipes were embedded into the panels which had three layers: a wooden frame $12 \mathrm{~mm}$ thick, an insulation layer $15 \mathrm{~mm}$ thick and an aluminium plate $3 \mathrm{~mm}$ thick. The aluminum plates helped a uniform surface temperature distribution. The floor was covered by plastic flooring on top.

\section{Ventilation strategy}

The ventilation strategy in the tests was exhaust ventilation. The supplied air was conditioned through the climatic air-conditioning system and a cool box. There were two arrangements of air inlet. With CR and FH systems, the air was supplied from a wall diffuser with a dimension of $215 \mathrm{~mm} \times 156 \mathrm{~mm}$ which located just above the window on the symmetry axis of the chamber. With VR, the air inlet was at the bottom and on the symmetry axis of the radiator which was used to supply the outside air into the room. Before getting into the channel 


\section{ACCEPTED MANUSCRIPT}

formed by the radiator panels, the air passes through a wall channel and a filter, which can prevent particles in the supplied air from reaching the indoor environment. The air exhaust terminal was on the bottom level at left side wall.

\section{Measuring instruments}

Figure 3 shows the measure points for air temperature, operative temperature, surface temperature and the reference point. The operative temperature $\left(T_{\mathrm{o}}\right)$ at the reference point, positioned in the center of the chamber with a height of $1.1 \mathrm{~m}$, was measured by a globe thermometer of a $40 \mathrm{~mm}$ diameter. The air temperature $\left(T_{\mathrm{a}}\right)$ at the reference point was measured by a thermistor shielded from radiant heat exchange. The relative humidity (RH) was recorded by a data logger having an accuracy of $\pm 2.5 \%$. The temperature sensors with data loggers together were calibrated in a range of $15^{\circ} \mathrm{C}$ to $26^{\circ} \mathrm{C}$ resulting on a temperature reading accuracy of $\pm 0.3{ }^{\circ} \mathrm{C}$. The air temperature and operative temperature were also tested at the edge of occupied zone close to the window at a height of $0.6 \mathrm{~m}$. Air velocity was measured at the reference point with heights of $0.1 \mathrm{~m}$ at foot level and $1.1 \mathrm{~m}$ at head level. Omnidirectional hot sphere anemometers were used and connected to a control unit multichannel flow analyser with an accuracy of $\pm(0.02+0.02 \cdot$ Reading $) \mathrm{m} / \mathrm{s}$.

The surface temperatures of window, radiator, floor and walls were measured by thermistor sensors with an accuracy of $\pm 0.3{ }^{\circ} \mathrm{C}$. The thermistor sensors were flat and in order to secure a good thermal contact with the surface, thermal paste and aluminum tape were used to cover the sensor.

The environment chamber no. 3 in DTU was used to calibrate temperature sensors. The chamber provided conditioned air uniformly from the floor to the ceiling and also passed through 


\section{ACCEPTED MANUSCRIPT}

the thin textile layers of the walls to control air temperature and radiant temperature. By means of this design the chamber had a low thermal mass to have the temperature changed rapidly.

A 23 body segment thermal manikin was used to calculate the clothing insulation (Tanabe et al. 1994; ISO 1991). There were two sets of the clothing worn during the tests one jacket-on and the other jacket-off. The overall clothing included underwear, T-shirts (cotton), long sleeve shirt, sports jacket and jeans. Tests of the manikin found that the clothing thermal insulation values were 1.07 with jacket and 0.74 without jacket.

\section{Human subjects survey}

The subjective survey was carried out by paper questionnaires that included specific questions (in accordance with ISO 10551) on overall thermal sensation, local thermal sensation, thermal comfort, thermal acceptability, draft acceptability, perceived air quality and also general questions on other indoor factors such as acoustic and illuminative comfort etc. (ASHRAE 2013; ISO 2005; Fanger et al. 1988; ISO 1995).

Fig. 4 shows the scales of surveyed items in the questionnaires. Thermal sensation was surveyed by the 7-points continuous scale (ISO 2005). Thermal comfort used a continuous scale ranged from comfortable to very uncomfortable: 4 (comfortable), 3 (slightly uncomfortable), 2 (uncomfortable), 1 (very uncomfortable). Acceptance of the thermal environment was voted by a split scale: 4 (clearly acceptable), 3 (just acceptable), 2 (just unacceptable), 1 (clearly unacceptable). Subjects were asked to vote on air movement which had the same numerical values as thermal acceptance. Perceived air quality was evaluated by air freshness ranging from fresh air to stuffy air which was split in the middle by points of "just fresh" and "just stuffy". The scale values were 1 (fresh air), 2 (just fresh), 3 (just stuffy), 4 (stuffy) (Fanger et al. 1988; ISO 


\section{ACCEPTED MANUSCRIPT}

1995; Gunnarsen and Fanger 1995).

Twenty four human subjects were selected to participate in the tests, 12 males and 12 females. They all had at least one and half years' living experience in the Nordic climate. They submitted to the requirements of being healthy, non-alcoholic and during the test period they avoided caffeine drinks and perfumes. The following table displays the subjects' anthropometric information. Measures of body mass index and body fat percentage (calculated by measuring the circumferences of certain body parts) (Hodgdon and Beckett 1999) identified a mix of normal weight, overweight, and obese subjects (WHO 2006).

Subjects were relaxed reading and typing on the laptop, so metabolic rate was evaluated as 1.0.

\section{Data analysis}

The subjective votes taken during the last hour of the experimental period (3.5 hours) were analyzed and the results from three different experimental conditions were compared regarding the votes of thermal sensation, thermal comfort, thermal acceptance and perceived air quality. The individual votes were plotted for each heating system. The mean values were compared in relation to different heating systems. The influence of the subjects' gender was also investigated. Statistical methods were performed to generate a significant reference. T-test method and Analysis of Variance (ANOVA) were used to determine the significance of the difference between the three heating systems.

In total, there were 72 tests and the sample size in each heating system was 24 . Resource limitation was one reason to fix the sample size, while the required sample size was also checked by power analysis of hypothesis test (Lenth 2001; Cohen 1988) as to be of scientific significance. 


\section{ACCEPTED MANUSCRIPT}

A two-sided test was set up with a required effect size and $80 \%$ power when the significant level was 0.05 . The required sample size was 15 for Paired T-test and required total sample size was 24 for two groups T-test. As a result, the sample size in this study was fixed as 24 . It may not be "big enough", however the sample data also broadened the study scope considering different anthropometric information, gender and multiple heating systems.

\section{Experiment Program}

\section{Experimental procedure}

The subjects have been exposed 2 by 2 to all three built environmental conditions for three and half hours each. In the beginning, subjects stayed in a neutral and uniform environment with air temperature of $22{ }^{\circ} \mathrm{C}$ for half an hour before entering into the test chamber. This was a preparation time to explain the questionnaires and to change the required clothing. After the test started, the first two hours were used to have the subjects reach a steady state on the metabolic level and a stable thermal sensation. Subjects recorded one vote at the end of the first hour and two votes in the second hour. At the last hour, subjects filled into the questionnaire every twenty minutes. See Fig. 5. During the test, subjects were free to take the jacket on or off in the first two hours, according to own thermal preference at home. At the start of the last hour, the subjects were prompted to decide whether to wear the jacket or leave it off.

\section{Boundary conditions and physical conditions measured}

The winter season is from November to March in most Nordic climates. The average winter temperature in Helsinki, Stockholm, and Copenhagen is around $-4^{\circ} \mathrm{C}, 0{ }^{\circ} \mathrm{C}$, and $5{ }^{\circ} \mathrm{C}$ respectively. Accommodating to the lowest temperature that air could be cooled, the supply air temperature 


\section{ACCEPTED MANUSCRIPT}

was set at $5{ }^{\circ} \mathrm{C}$ for the three heating cases. It was not an extreme winter temperature but this temperature level can be a preliminary exploration from the perspective of subjective surveys.

In residential buildings, the required air changes rate (ach, $1 / \mathrm{h})$ is no less than 0.5 ach to 1 ach. Meanwhile according to the minimum fresh air needed which is $0.351 / \mathrm{s} \mathrm{per} \mathrm{m}^{2}$ and $61 / \mathrm{s}$ per person for an acceptable indoor environment in building regulations, the air changes rate used in the test was 1 ach which meant air supply volume was 12.6 l/s for the chamber with two subjects (BBR 2011; D2 2012).

The simulated window's inner surface temperature was calculated according to outdoor air temperature $T_{\text {out }}$, indoor air temperature $T_{a}$ and heat transfer coefficient of window $U$ and surface heat transfer coefficient $h$. See Eq. (1).

$T_{\text {surface }}=T_{a}-\frac{U}{h}\left(T_{a}-T_{\text {outside }}\right)$

where $h$ is heat transfer coefficient in an average condition including the effects of convection

and radiation heat transfer. An average value of $7.6 \mathrm{~W} /\left(\mathrm{m}^{2} \mathrm{~K}\right)$ was used according to findings by others (Griffin et al. 1996; Moshfeg et al. 1999; Jurelionis and Isevicius 2008).

The internal heat loads included metabolic heat production $(60 \mathrm{~W} /$ person), four lights $(72$ $\mathrm{W})$, and two laptops $(80 \mathrm{~W})$. Table 2 shows the boundary conditions for the test design and table 3 shows the physical conditions measured during the tests as a comparison. For the air velocity, only mean values higher than $0.05 \mathrm{~m} / \mathrm{s}$ are listed. Only with floor heating system, a mean air velocity was measured higher than $0.15 \mathrm{~m} / \mathrm{s}$. The surface temperature of window, radiator and floor shown in the table is an average value calculated from several sensors along the surface. From the measurements, the water supply temperature to $\mathrm{CR}, \mathrm{VR}$ and $\mathrm{FH}$ system was $44{ }^{\circ} \mathrm{C}$, 


\section{ACCEPTED MANUSCRIPT}

$35{ }^{\circ} \mathrm{C}$ and $30{ }^{\circ} \mathrm{C}$ respectively which meant the three heating systems were operating as low temperature and even very low temperature heating systems (Eijdems and Boerstra 2000).

The clo values were observed during the test. See Fig.6, showing the clo levels of each subject in the test of different heating systems. In average, the clo value of female is $1.06 \pm 0.05$; the clo value of male is $0.8 \pm 0.13$.

\section{Results}

\section{The distribution of experimental data from human subject tests}

The individual votes in each heating system are shown in Fig. 7 in detail: thermal sensation vote, thermal comfort vote, thermal acceptability vote, perceived air quality vote and draft acceptability vote. Each diagram displays standard deviation, mean value, median value and min and max values. The mean vote in each heating system is connected with a trend line. The standard deviation reveals individual differences existing on the surveyed variables.

The mean value of the sample results was calculated and described as a range with a $95 \%$ confidence interval. The interval means there is $95 \%$ probability that the mean value will fall within this range. Thus, instead of only the mean value, it makes sense to give the entire range representing different perceived levels with each heating system. See table 4. The result of thermal sensation is between neutral to slightly cool for the three heating systems. The results of thermal acceptability and perceived air quality are in the range of just acceptable and just fresh respectively. It's slightly uncomfortable in $\mathrm{CR}$ and $\mathrm{FH}$ and slightly uncomfortable to comfortable in VR. Draft acceptability in CR is clearly acceptable, in FH is just acceptable and in VR is just acceptable to clearly acceptable. 


\section{ACCEPTED MANUSCRIPT}

\section{The influences of heating system and gender on thermal perceptions and perceived air quality}

The mean values shown in table 4 do not represent any significant differences. The following analysis of variance (ANOVA) was used to verify the influences of heating system and gender on the voting results. The significant test level is 0.05 . Table 5 shows the significant $\mathrm{p}$ value. Results indicate that the two factors of heating system and gender both have significant influence. Heating systems have significantly effects on thermal acceptability and draft acceptability. There is no significant difference in thermal sensation between the three heating systems which agrees with the result in table 4 . This is also the same result of perceived air quality. As for thermal comfort, there is no significant influence from heating systems although a different level of mean vote can be observed in table 4 . As for gender, it has a significant influence on thermal sensation and draft acceptability. The cross influence of heating system and gender is not significant to the surveyed variables.

\section{The comparison of mean values under different heating system}

Paired T-test is used to compare the means. In Fig.8, the mean values of thermal acceptability are given with a $95 \%$ confidence interval. The numerical value is from the voting scale. The corresponding perception is listed on the vertical axis. Even though the mean values of the three heating systems are in the same level of just acceptable, the minor differences between $\mathrm{CR}$ and FH, and VR and FH are significant. The result is interpreted as subjects feel a bit more comfortable in CR and VR comparing with FH.

The perceived levels of the air draft in each heating system shows significant differences. See Fig. 9. Regarding how the subjects felt the air movement, the mean values of draft 


\section{ACCEPTED MANUSCRIPT}

acceptability in CR and VR are significantly different from FH: it is clearly acceptable in CR and VR and just acceptable in FH.

\section{The comparison of mean values under different gender group}

To track gender's significant influence on thermal sensation and draft acceptability, the following figures compare the difference of mean values in each gender group in the surveyed variables and heating systems. T-test is used to compare the means in a significant level of 0.05 .

Fig. 10 shows the mean values of thermal sensation perceived by males and females. The left diagram divides the gender group from the total samples in the three heating systems. The result shows the difference of numerical values between females and males is significant. Females feel warmer than males for which the sensation is between slightly cool to neutral and the latter is slightly cool. This significant difference is also found in CR system for which females feel neutral and males feel slightly cool as shown in the right diagram.

The subjects also experienced air movement differently by gender. See Fig. 11 which shows the mean values of draft acceptability. If data from the three heating systems is divided by gender, the acceptance of cold draft in the female group (clearly acceptable) is somewhat higher than in the male group (just acceptable).

The mean values' comparison for the other surveyed variables of thermal comfort, thermal acceptance and perceived air quality are not presented here as there is no significant gender difference shown between the different heating system. 


\section{ACCEPTED MANUSCRIPT}

\section{Perceived cold sense on partial body segment under different heating system}

The percentage of subjects who experienced a cold feeling on a specific body segment is displayed in Fig.12. Subjects were asked to log their perceptions of cold on 11 body parts including back, shoulder, neck, head, face, chest, arm, hands, thigh, lower leg and feet. The percentage of the perceived cold sensation was calculated from the votes. In all three heating systems, as high as $70 \%$ of the subjects reported cold feet. In the lower leg region, more subjects reported a cold sensation in FH, followed by CR and then VR. There were also more cold feelings reported in hands, face, neck and chest with the floor heating system. By contrast, fewer subjects reported cold sensations in the partial body segment in VR.

\section{Discussion}

\section{Comparisons of three low temperature heating systems on perceived thermal environment}

The above results in table 5 show no significant difference in thermal sensation and thermal comfort between the three heating systems. Compared to the conventional radiator, the ventilation radiator operating at a lower water temperature did not show any disadvantage within the perceived thermal environment. Further the conventional radiator operating in low temperature heating system satisfied basic thermal comfort. From an energy efficiency point of view, ventilation radiator promises to provide a comfortable indoor environment while simultaneously requiring a lower water supply temperature.

There were however differences in thermal acceptability (Fig. 8), CR and VR. The radiator systems were perceived as more acceptable than the floor heating system. The vote of draft acceptability (Fig. 9) was also a bit lower in the floor heating system compared to the radiator 


\section{ACCEPTED MANUSCRIPT}

systems which is statistically significant. Floor heating systems using large hydronic radiant surface have been found to provide a more uniform temperature profile and provide better thermal comfort in comparison with high temperature water based systems and other convective systems (Myhren and Holmber 2008). To avoid the risk of down-draft, floor heating systems are often combined with balanced ventilation and heat recovery to supply an air temperature higher than $15{ }^{\circ} \mathrm{C}$. However in this study, an exhaust ventilation was deployed in the study's floor heating system. The "outdoor" air was supplied directly into the room at the outside wall. As a result in Fig. 12, more cold perceptions from partial body segment were logged in FH than in CR and VR. This might be one possible reason why floor heating did not show the same level of thermal acceptability and draft acceptability as radiator systems.

In all these three heating systems, it was observed that subjects reported cold sensations on the lower parts of the body especially on the feet which is shown in Fig. 12. It's possible to be caused by a cold down-draft or a low air temperature above the floor. Compared to conventional radiator system (high water temperature supply), low temperature radiator systems have a lower surface temperature. When the outdoor air conducted into the room pass by the radiator and drop down to the floor, cold draft is a great potential for the occupants.

The study found that mean thermal sensations in the three heating systems tended to be

slightly cool which is lower than what was expected with an operative temperature of above $22.5^{\circ} \mathrm{C}$. From previous studies, it's known that local thermal sensation has a significant influence on overall thermal sensation and local discomfort may cause an overall discomfort perception (Arens et al. 2006; Jin et al. 2011). Hence, the cold sensations in the lower extremities part might be the main reason for the actual thermal sensations' bias from the neutral condition. 


\section{ACCEPTED MANUSCRIPT}

\section{Thermal adaptive behavior with clothing change}

The results from section 4.4 show that males perceived the indoor environment to be a bit colder and felt more draftier than females. To explain this, one premise of the experiment cannot be neglected. In this study, the clothing level is not fixed, as being free to adjust one's clothing is a primary thermal adaptive behavior. The clothing resistance value was 1.07 with jacket and 0.74 without jacket. Apparently females in all three heating systems wore a jacket with the exception of one subject in VR who did not wear a jacket. Conversely, most of male subjects preferred no jacket in all thermal conditions. Since different clothing levels have significant influences on thermal sensations as Fanger's PMV model showed, the clothing values can explain why males perceived colder than females in this study. Low clothing value may also has played a role in the gender differences in perceived draft (higher in males than in females).

However, the overall results of thermal comfort found no significant difference between males and females. Subjects can reach thermal comfort even though thermal sensation can be in a different level. It indicates male prefer a colder thermal sensation than female do. Adjusting the clothing according to personal thermal preference is a type of thermal adaptive behavior which is a way of reaching thermal comfort while simultaneously enabling savings in energy consumption.

\section{Possibility and limitation for low temperature heating systems with exhaust ventilation}

When outdoor air temperature was $5^{\circ} \mathrm{C}$, the three heating methods can satisfy basic thermal requirements. With additional renovation on the window's conductive heat transfer coefficient, the thermal comfort and draft-down could be further improved. In this study, air supply temperature was not recommended lower than $5{ }^{\circ} \mathrm{C}$, and the window's $U$ value could not be set 


\section{ACCEPTED MANUSCRIPT}

up higher than $2.1 \mathrm{~W} /(\mathrm{m} 2 \mathrm{~K})$. If these had been set up exceeding the values, it is likely the subjects would have reported more local discomfort and cold draft will be probably more obvious.

Regarding the subjects' anthropometric information, the subject group included both normal weight and overweight people and females and males. As a result, the conclusions are representative of the general populace. However, the study has some limitations. The limited pool of data from 24 human subject cannot provide definitive results, though it did provide useful data that supports specific conclusions of the phenomena. The study also has some time and facility limitation. The outdoor air temperature of $5{ }^{\circ} \mathrm{C}$ cannot represent the entire temperature spectrum in the Nordic heating season. Additional combinations of outdoor air temperature and window and wall's U values which representing more favorable / unfavorable conditions could be studied in the future to provide a boundary of installing low temperature radiator systems and floor heating when a building slated to be retrofitted with exhaust air ventilation.

\section{Conclusions}

The perceived thermal environment can be satisfied in all three heating systems with the following boundary conditions: water supply temperature lower than $45^{\circ} \mathrm{C}$, window's $\mathrm{U}$ value

of 2. $1 \mathrm{~W} /\left(\mathrm{m}^{2} \mathrm{~K}\right)$, exhaust- ventilated room, outdoor air temperature of $5{ }^{\circ} \mathrm{C}$, and room temperature of $22{ }^{\circ} \mathrm{C}$. There are no significant differences in thermal sensation and thermal comfort vote between the three heating systems. Thermal acceptability has a minor difference between the radiator systems and the floor heating system. Draft acceptability is different in the 


\section{ACCEPTED MANUSCRIPT}

three heating systems but all three are at least "just acceptable". Perceived air quality in three heating systems shows no significant difference. Compared to the conventional radiator, the ventilation radiator operating at a lower water supply temperature does not demonstrate disadvantages on the perceived thermal environment. From an energy efficiency point of view, ventilation radiator promises a comfortable indoor environment with a decreased water supply temperature. Compared to the radiator systems, floor heating with exhaust ventilation can provide a basic thermal comfort level, which suggests retrofitting that includes exhaust ventilation may offer another solution.

Gender has significant influences on thermal sensation and draft acceptability. Males feel colder and more draft than females. But this also correlates to the apparent preference that males preferred no jacket while female preferred to wear a jacket. No significant difference is in thermal comfort. Adjusting the clothing according to personal thermal preference is a way of reaching thermal comfort while simultaneously enabling savings in energy consumption.

It is found that in all three heating methods, $70 \%$ subjects experienced cold sensations in their feet. More subjects felt cold in the lower leg level in floor heating, followed by conventional radiator and then ventilation radiator. The sensation of cold in the lower extremities is the main reason for the actual thermal sensation's bias from the neutral condition, even when

the operative temperature in the central point was satisfied. One possible explanation for this difference between floor heating and the radiator systems is the draft generated by the exhaust ventilation system.

To improve the perceived indoor environment for low temperature heating systems with exhaust air ventilation systems, the draft level must be reduced. Toward this end, lowering the 


\section{ACCEPTED MANUSCRIPT}

window's conductive heat transfer coefficient is one potential way to reduce draft-down and improve perceived thermal comfort.

As a limitation from this study, more combinations of outdoor air temperatures and envelope's $\mathrm{U}$ values could be studied in the future to provide a boundary of applying low temperature radiator systems and floor heating system with exhaust ventilation in building retrofit.

\section{Acknowledgements}

Financial supports from KTH Royal Institute of Technology and research platform from Nordic Built 13339 project are gratefully acknowledged. Many thanks to the supports from Mikko livonen in Rettig ICC, Pekka Tuomaala in VTT Finland and Hesaraki Arefeh in KTH. 


\section{ACCEPTED MANUSCRIPT}

\section{Reference}

ASHRAE. 2013. ASHRAE Standard 55-2013 (Thermal Environmental Conditions for Human Occupancy). Atlanta, ASHRAE, Inc.

Arens E., Zhang H., Huizenga C. 2006. Partial- and Whole-body Thermal Sensation and Comfort, Part I: Uniform Environmental Conditions. Journal of Thermal Biology, 31:53-59.

Brand M., Thorsen J.E., Svendsen S. 2012. Numerical modelling and experimental measurements for a low-temperature district heating substation for instantaneous preparation of DHW with respect to service pipes. Energy, 41(1): 392-400.

Boerstra A., Veld P.O., Eijdems H. 2009. The health, safety and comfort advantages of low temperature heating systems: a literature review. Proceedings of the 6th International Conference on Healthy Buildings, 2: 629-634.

Babiak J., Olesen B.W., Petras D. 2013. Low temperature heating and high temperature cooling. Belgium, REHVA.

Bluyssen P.M. 2000. EPIQR and IEQ: indoor environment quality in European apartment buildings. Energy and Buildings, 31 (2): 103-110.

Building Regulations BBR 19. 2011. Mandatory provisions and general recommendations, BFS 2011: 26. Swedish Board of Housing, Building and Planning.

Causone F., Baldin F., Olesen B.W., Corgnati S.P. 2010. Floor heating and cooling combined with displacement ventilation: Possibilities and limitations. Energy and Building, 42(12): $2338-2352$.

Cohen J. 1988. Statistical Power Analysis for the Behavioral Sciences (2nd ed.). New York: Academic Press, New York. 


\section{ACCEPTED MANUSCRIPT}

D2 Finnish Code of Building Regulations. 2012. Ministry of the Environment Department of Housing and Construction, Indoor Climate and Ventilation of Buildings Regulations and Guidelines.

Eijdems H.H.E.W., Boerstra A.C. 2000. Low temperature heating systems: impact on IAQ. Thermal comfort and energy consumption, Annex 37 newsletter 1.

Fanger P.O., Lauridsen J., Bluyssen P., Clausen G. 1988. Air Pollution Sources in Offices and Assembly Halls, Quantified by the olf Unit. Energy and Building, 12: 7-19.

Fanger, P.O. 1970. Thermal Comfort: Analysis and Applications in Environmental Engineering, Copenhagen, Danish Technical Press.

Gunnarsen L., Fanger P.O. 1992. Adaptation to indoor air pollution. Environment International, 18: 43-54.

Griffin B.T., Turler D., Arasteh D. 1996. Surface temperatures of insulated glazing units: infrared thermography laboratory measurements. ASHRAE Transactions, 102: 2.

Hodgdon J.A., Beckett M.B.1999. Development of the DoD Body Composition Estimation Equations. San Diego, Naval Health Research Center.

IS0/DIS-9920. 1991. Ergonomics of the thermal environment--Estimation of the thermal insulation and Evaporative resistance of a clothing ensemble. Geneva: International Organization for standardization.

ISO 7730. 2005. Ergonomics of the thermal environment e Analytical determination and interpretation of thermal comfort using calculation of the PMV and PPD indices and local thermal comfort criteria. International Organisation for Standardization. 


\section{ACCEPTED MANUSCRIPT}

ISO 10551. 1995. Ergonomics of the thermal environment - Assessment of the influence of the thermal environment Using subjective judgement scales. International Organisation for Standardization.

Jurelionis A., Isevicius E. 2008. CFD predictions of indoor air movement induced by cold window surfaces. Journal of Civil Engineering and Management, 14(1): 29-38.

Jin Q., Duanmu L., Zhang H., Li X.L., Xu H.B.2011. Thermal sensations of the whole body and head under local cooling and heating conditions during step-changes between workstation and ambient environment. Building and Environment, 46(11): 2342-2350.

Karjalainen S. Thermal comfort and gender: a literature review. Indoor air, 22(2): 96-109.

Lenth R.V. 2001. Some practical guidelines for effective sample size determination. The American Statistician, 55(3): 187-193.

Myhren J.A., Holmberg S. 2009. Design considerations with ventilation-radiators: Comparisons to traditional two-panel radiators. Energy and Buildings, 41(1): 92-100.

Maivel M., Kurnitski J. 2014. Low temperature radiator heating distribution and emission efficiency in residential buildings. Energy and Buildings, 69: 224-236.

Myhren J.A., Holmberg S. 2013. Performance evaluation of ventilation radiators. Applied Thermal Engineering, 51(1-2): 315-324.

Myhren J.A. 2011. Potential of ventilation radiators: performance evaluation by numerical, analytical and experimental investigation. Doctoral thesis in civil and architectural engineering, Stockholm, Sweden: KTH Royal Institute of Technology. 


\section{ACCEPTED MANUSCRIPT}

Moshfeg B., Larsson U., Sandberg M. 1999. Thermal analysis of super insulated windows (numerical and experimental investigations). Journal of Energy and Buildings, 29(2): 121128.

Myhren J.A., Holmberg S. 2008. Flow patterns and thermal comfort in a room with panel, floor and wall heating. Energy and Buildings, 40(4): 524-536.

Olesen B.W., Mortensen E., Thorshauge J., Berg-munch B. 1980. Thermal comfort in a room heated by different methods, Technical paper no. 2256, Los Angeles Meeting, ASHRAE Transactions 86.

Ploskić A., Holmberg S. 2013. Low-temperature ventilation pre-heater in combination with conventional room heaters, Energy and Buildings, 65: 248-259.

Svensk Fjärrvärme AB. 2009. Heating in multi-family dwellings and commercial buildings (in Swedish), Rapport I: 4, ISBN 978-91-7381-019-7.

Tobias B., Wolfgang E., Rainer E. (Fraunhofer ISI). 2012. Policy Report: Contribution of Energy Efficiency Measures to Climate Protection within the European Union until 2050. Germany, Federal Ministry for the Environment, Nature Conservation and Nuclear Safety and Fraunhofer Institute for Systems and Innovation Research ISI. http://www.isi.fraunhofer.de/isiwAssets/docs/e/de/publikationen/BMU_Policy_Paper_20121022.pdf (assessed April 30, 2016)

Toftum J., Langkilde G., Fanger P.O. 2004. New indoor environment chambers and field experiment offices for research on human comfort, health and productivity at moderate energy expenditure. Energy and Building, 36(9), 899-903. 


\section{ACCEPTED MANUSCRIPT}

Tanabe S., Arens E.A., Bauman F.S., Zhang H., Nladsen T.L. 1994. Evaluating thermal environments by using thermal manikin with controlled skin surface temperature. ASHRAE Transaction, 100(1): 39-48.

Wargocki P., Sundell J., Bischof W., Brundrett G., Fanger P.O., Gyntelberg F., Hanssen S.O., Harrison P., Pickering A., Seppänen O., Wouters P. 2002. Ventilation and health in nonindustrial indoor environments: report from European multidisciplinary scientific consensus meeting (EUROVEN). Indoor Air 12 (2): 113-128.

WHO. 2006. Global Database on Body Mass Index: BMI Classification. World Health Organization. http://apps.who.int/bmi/index.jsp?introPage=intro_3.html (assessed Mar.15, 2016)

Zalejska-Jonsson A., Wilhelmsson M. 2013. Impact of perceived indoor environment quality on overall satisfaction in Swedish dwellings. Building and Environment, 63: 134-144. 


\section{ACCEPTED MANUSCRIPT}

Table 1. Subject anthropometric information

\begin{tabular}{|c|c|c|c|c|c|}
\hline Gender & $\begin{array}{c}\text { Age ( mean } \\
\pm \text { SD) }\end{array}$ & $\begin{array}{c}\text { Weight, kg } \\
(\text { mean } \pm \\
\text { SD) }\end{array}$ & $\begin{array}{c}\text { Height, cm } \\
(\text { mean } \pm \\
\text { SD) }\end{array}$ & $\begin{array}{c}\text { Body mass } \\
\text { index } \\
(\text { mean } \pm \\
\text { SD) }\end{array}$ & $\begin{array}{c}\text { Body fat } \\
\text { percentage, \% } \\
(\text { mean } \pm \text { SD) }\end{array}$ \\
\hline Female & $27 \pm 5.1$ & $64.4 \pm 10.9$ & $164.0 \pm 6.0$ & $23.9 \pm 4.0$ & $32.5 \pm 7.1$ \\
\hline Male & $27 \pm 3.6$ & $80.9 \pm 11.1$ & $178.3 \pm 6.8$ & $25.4 \pm 2.9$ & $20.9 \pm 4.6$ \\
\hline
\end{tabular}




\section{ACCEPTED MANUSCRIPT}

Table 2. Boundary conditions

\begin{tabular}{|c|c|c|c|c|}
\hline $\begin{array}{c}\text { Room operative } \\
\text { temperature } \\
\left(\boldsymbol{T}_{\mathbf{0}}\right),{ }^{\circ} \mathbf{C}\end{array}$ & $\begin{array}{c}\text { Air supply } \\
\text { temperature } \\
\left(\boldsymbol{T}_{\boldsymbol{s}}\right),{ }^{\circ} \mathbf{C}\end{array}$ & $\begin{array}{c}\text { Air supply } \\
\text { volume }\left(\boldsymbol{q}_{\boldsymbol{s}}\right), \\
\mathbf{l} / \mathbf{s}\end{array}$ & $\begin{array}{c}\text { Window's surface } \\
\text { temperature } \\
\left(\boldsymbol{T}_{\text {surface }}\right),{ }^{\circ} \mathbf{C}\end{array}$ & $\begin{array}{c}\text { Internal } \\
\text { heat load, } \\
\text { W }\end{array}$ \\
\hline 22 & 5 & 12.6 & 16.6 & 392 \\
\hline
\end{tabular}




\section{ACCEPTED MANUSCRIPT}

Table 3. Physical conditions from the measurements

\begin{tabular}{|c|c|c|c|c|c|c|c|}
\hline $\begin{array}{c}\text { Avera } \\
\text { ge } \pm \\
\text { SD }\end{array}$ & $\begin{array}{c}\text { Room } \\
\text { operative } \\
\text { temperatu } \\
\text { re }\left(T_{0}\right),{ }^{\circ} \mathrm{C}\end{array}$ & $\begin{array}{l}\text { Room air } \\
\text { temperatu } \\
\text { re }\left(T_{\mathrm{a}}\right),{ }^{\circ} \mathrm{C}\end{array}$ & $\begin{array}{c}\text { Air } \\
\text { supply } \\
\text { temperatu } \\
\operatorname{re}\left(T_{s}\right),{ }^{\circ} \mathrm{C}\end{array}$ & $\begin{array}{c}\text { Air } \\
\text { suppl } \\
\text { y } \\
\text { volu } \\
\text { me } \\
\left(q_{s}\right), \\
\text { l/s }\end{array}$ & $\begin{array}{c}\text { Window's } \\
\text { surface } \\
\text { temperatu } \\
\text { re } \\
\left(T_{\text {surface }}\right),^{\circ} \\
\text { C }\end{array}$ & $\begin{array}{c}\text { Radiator } \\
\text { surface } \\
\text { temperatu } \\
\text { re }\left(T_{r}\right),{ }^{\circ} \mathrm{C}\end{array}$ & $\begin{array}{c}\text { Floor } \\
\text { Surface } \\
\text { temperatu } \\
\text { re }\left(T_{f}\right),{ }^{\circ} \mathrm{C}\end{array}$ \\
\hline $\mathrm{CR}$ & $22.7 \pm 0.2$ & $21.7 \pm 0.2$ & $5.1 \pm 0.3$ & 12.6 & $16.6 \pm 0.1$ & $37.7 \pm 0.6$ & $21.7 \pm 0.1$ \\
\hline VR & $22.9 \pm 0.1$ & $21.9 \pm 0.1$ & $5.0 \pm 0.2$ & 12.6 & $16.6 \pm 0.2$ & $27.0 \pm 0.1$ & $21.3 \pm 0.2$ \\
\hline $\mathrm{FH}$ & $22.8 \pm 0.2$ & $21.7 \pm 0.2$ & $4.9 \pm 0.4$ & 12.6 & $16.6 \pm 0.2$ & $21.0 \pm 0.2$ & $23.4 \pm 0.4$ \\
\hline $\begin{array}{c}\text { Avera } \\
\text { ge } \pm \\
\text { SD }\end{array}$ & $\begin{array}{c}\text { Air } \\
\text { velocity at } \\
0.1 \mathrm{~m} \\
(\mathrm{~m} / \mathrm{s}) \\
\end{array}$ & $\begin{array}{c}\text { Air } \\
\text { velocity at } \\
1.1 \mathrm{~m} \\
(\mathrm{~m} / \mathrm{s}) \\
\end{array}$ & & & & & \\
\hline CR & $\begin{array}{c}0.07 \pm \\
0.02\end{array}$ & $\begin{array}{c}0.07 \pm \\
0.02\end{array}$ & & & & & \\
\hline VR & $<0.05$ & $<0.05$ & & & & & \\
\hline $\mathrm{FH}$ & $\begin{array}{c}0.15 \pm \\
0.03\end{array}$ & $\begin{array}{c}0.05 \pm \\
0.03\end{array}$ & & & & & \\
\hline
\end{tabular}




\section{ACCEPTED MANUSCRIPT}

Table 4. Mean votes of thermal perceptions and perceived air quality in a range of $95 \%$ confidence interval in different heating system

\begin{tabular}{|c|c|c|c|c|c|}
\hline $\begin{array}{c}\text { Mean vote } \\
\text { range of } 95 \% \\
\text { confidence } \\
\text { interval }\end{array}$ & $\begin{array}{l}\text { Thermal } \\
\text { sensation }\end{array}$ & $\begin{array}{l}\text { Thermal } \\
\text { comfort }\end{array}$ & $\begin{array}{c}\text { Thermal } \\
\text { acceptability }\end{array}$ & $\begin{array}{c}\text { Draft } \\
\text { acceptability }\end{array}$ & $\begin{array}{l}\text { Perceived } \\
\text { air quality }\end{array}$ \\
\hline $\mathrm{CR}$ & \multirow{3}{*}{$\begin{array}{l}\text { Neutral to } \\
\text { slightly } \\
\text { cool }\end{array}$} & $\begin{array}{l}\text { Slightly } \\
\text { uncomfortable }\end{array}$ & \multirow{3}{*}{$\begin{array}{c}\text { Just } \\
\text { acceptable }\end{array}$} & $\begin{array}{l}\text { Clearly } \\
\text { acceptable }\end{array}$ & \multirow{3}{*}{ Just fresh } \\
\hline VR & & $\begin{array}{l}\text { Slightly } \\
\text { uncomfortable to } \\
\text { comfortable }\end{array}$ & & $\begin{array}{l}\text { Just acceptable } \\
\text { to clearly } \\
\text { acceptable }\end{array}$ & \\
\hline $\mathrm{FH}$ & & $\begin{array}{l}\text { Slightly } \\
\text { uncomfortable }\end{array}$ & & Just acceptable & \\
\hline
\end{tabular}




\section{ACCEPTED MANUSCRIPT}

Table 5. ANOVA analysis of different heating system and gender (values with * are significant in a level of $\mathrm{p}=0.05$ )

\begin{tabular}{|c|c|c|c|c|c|}
\hline $\begin{array}{c}\text { Significant } \\
\text { p value (p } \\
\text { < 0.05) }\end{array}$ & $\begin{array}{c}\text { Thermal } \\
\text { sensation }\end{array}$ & $\begin{array}{c}\text { Thermal } \\
\text { comfort }\end{array}$ & $\begin{array}{c}\text { Thermal } \\
\text { acceptability }\end{array}$ & $\begin{array}{c}\text { Draft } \\
\text { acceptability }\end{array}$ & $\begin{array}{c}\text { Perceived } \\
\text { air quality }\end{array}$ \\
\hline $\begin{array}{c}\text { Heating } \\
\text { system }\end{array}$ & 0.68 & 0.06 & $0.03^{*}$ & $0.001^{*}$ & 0.47 \\
\hline Gender & $0.03^{*}$ & 0.9 & 0.5 & $0.001^{*}$ & 0.7 \\
\hline $\begin{array}{c}\text { Heating } \\
\text { system \& } \\
\text { Gender }\end{array}$ & 0.06 & 0.7 & 0.8 & 0.8 & 0.12 \\
\hline
\end{tabular}




\section{ACCEPTED MANUSCRIPT}

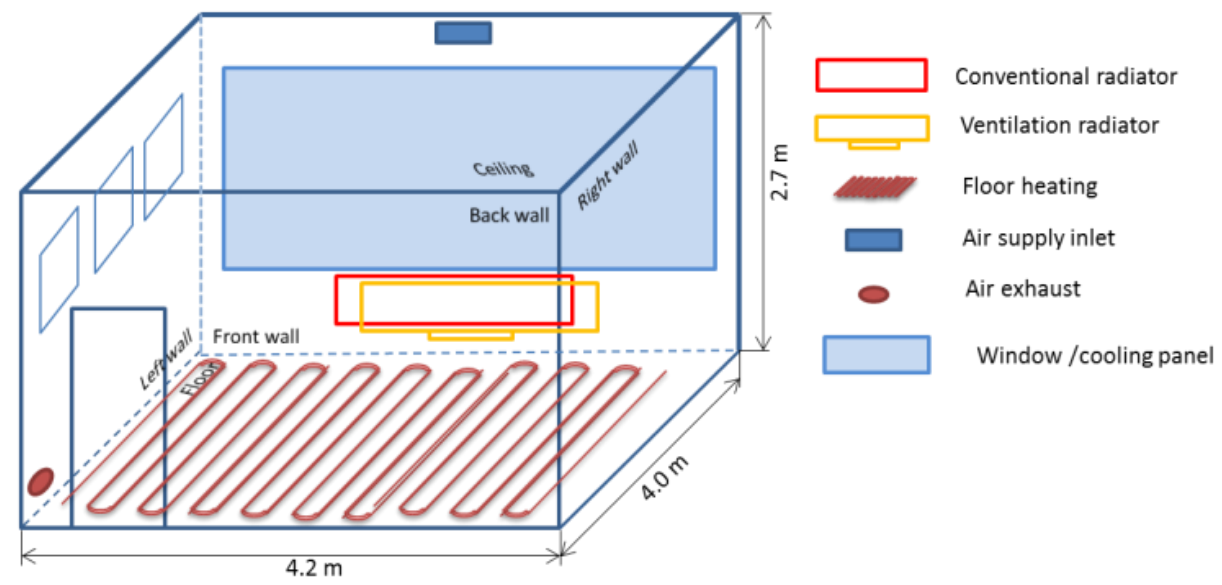

Figure 1. The layout of indoor environment chamber 


\section{ACCEPTED MANUSCRIPT}

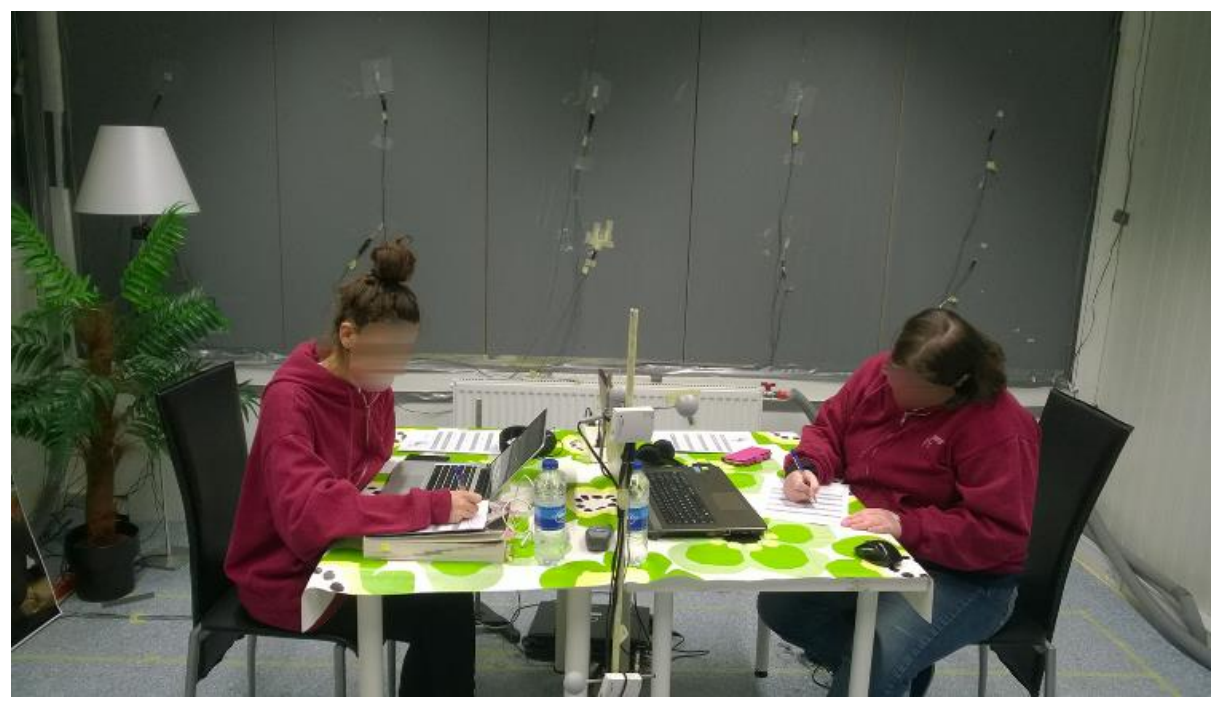

Figure 2. The indoor environment chamber during the tests with human subjects 


\section{ACCEPTED MANUSCRIPT}

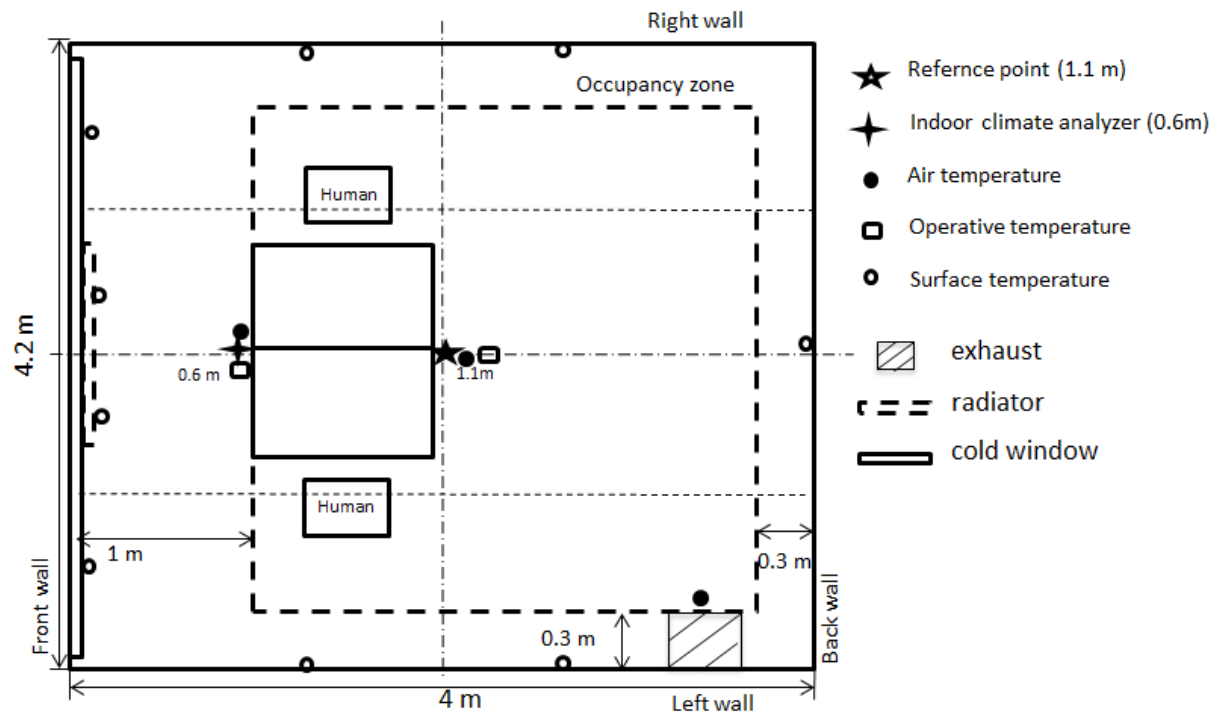

Figure 3. The layout of indoor environment chamber with measurement points 


\section{ACCEPTED MANUSCRIPT}

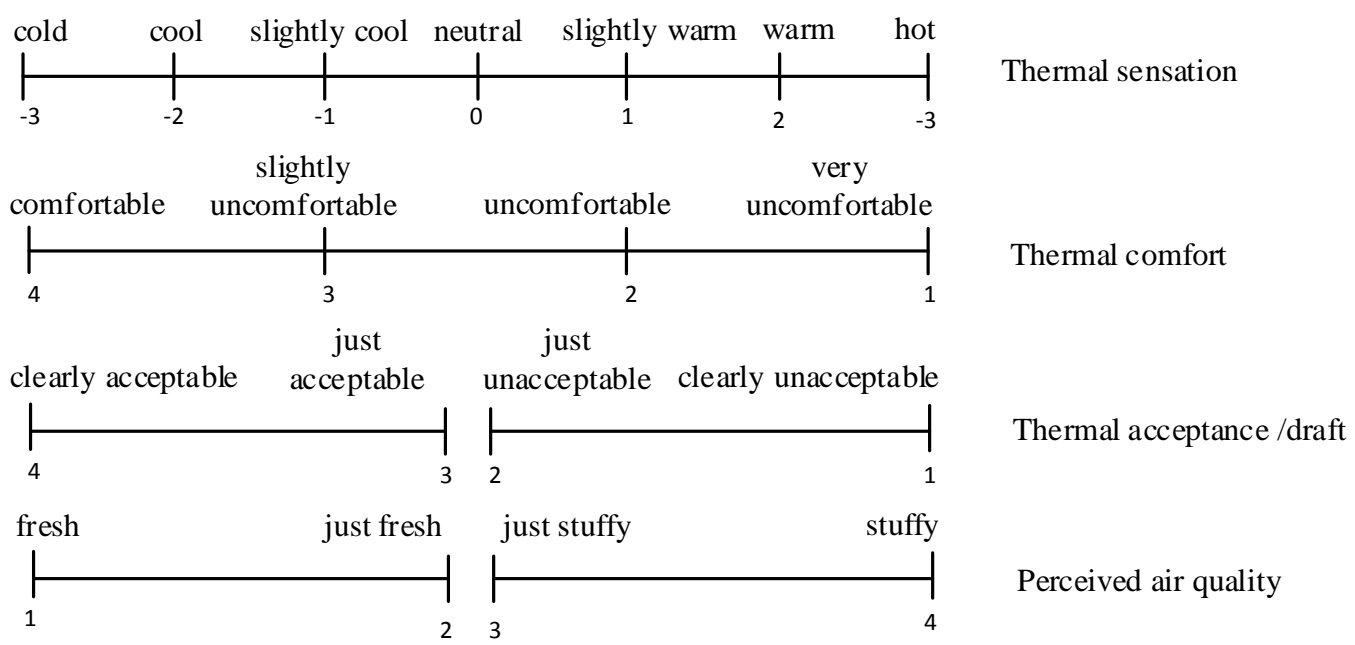

Figure 4. The scales used in the questionnaires 


\section{ACCEPTED MANUSCRIPT}

\begin{tabular}{|c|c|c|c|c|}
\hline 30 minutes & $1 \mathrm{~h}$ & $2 \mathrm{~h}$ & $3 \mathrm{~h}$ & \\
\hline $\begin{array}{l}\text { Metabolic } \\
\text { steady state }\end{array}$ & $60 \mathrm{~min}$ & $90 \mathrm{~min} \quad 120 \mathrm{~min}$ & $140 \mathrm{~min} \vdots 160 \mathrm{~min}$ & $180 \mathrm{~min}$ \\
\hline
\end{tabular}

Q: questionnaire answer

Figure 5. Human subject test schedule 


\section{ACCEPTED MANUSCRIPT}

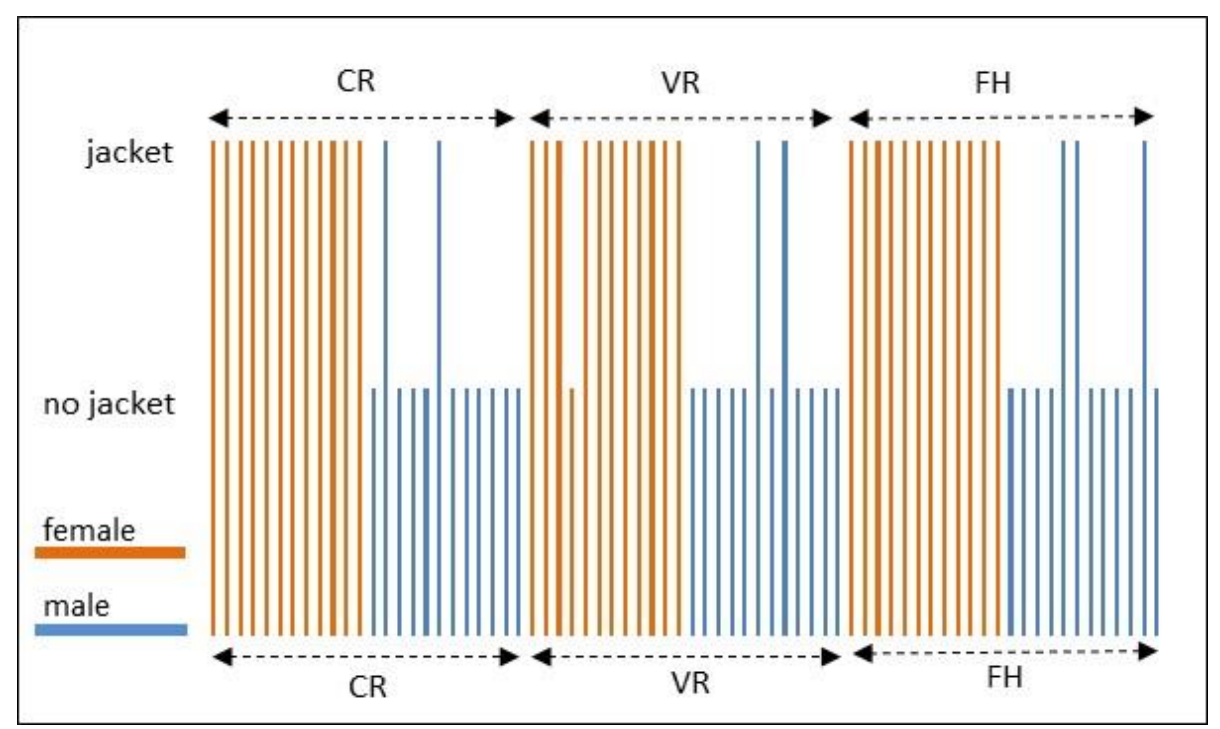

Figure 6. Clothing information for each subject in different heating system 


\section{ACCEPTED MANUSCRIPT}
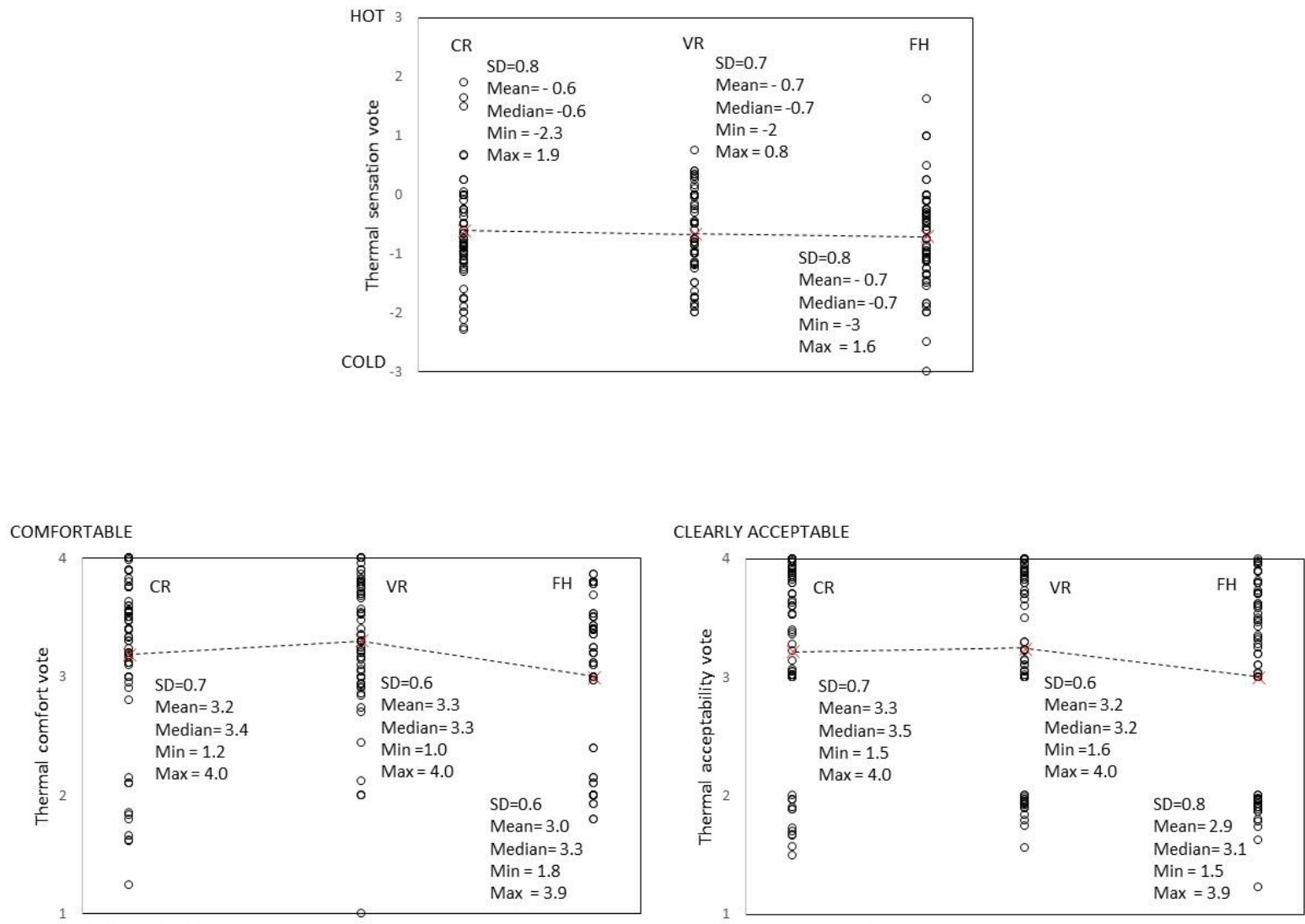

VERY UNCOMFORTABLE

CLEARLY UNACCEPTABLE

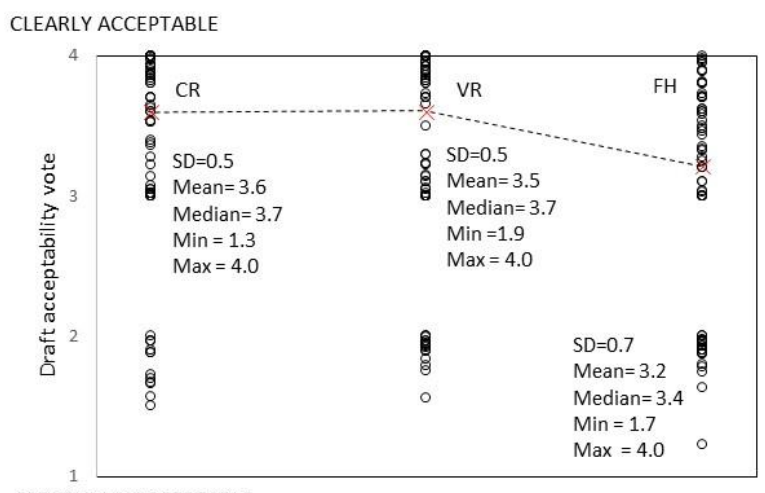

CLEARLY UNACCEPTABLE

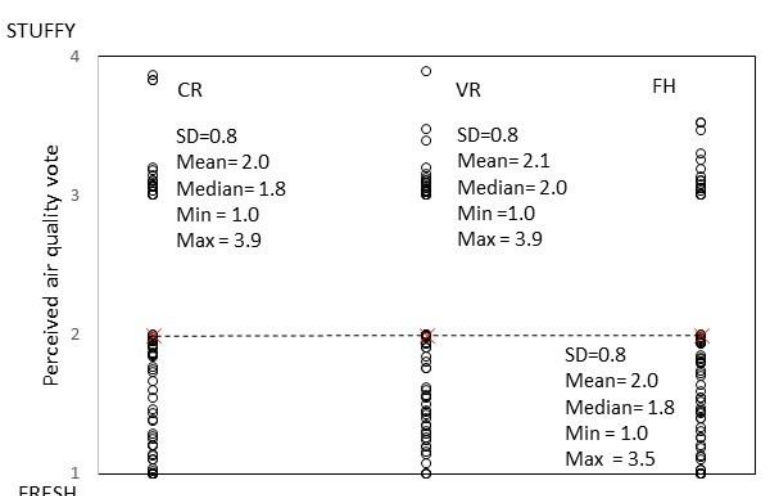

Figure 7. Distribution of individual votes under different heating systems (Diagram shows standard deviation, mean value, median value, min and max values. The line connects the mean value between different heating systems) 


\section{ACCEPTED MANUSCRIPT}

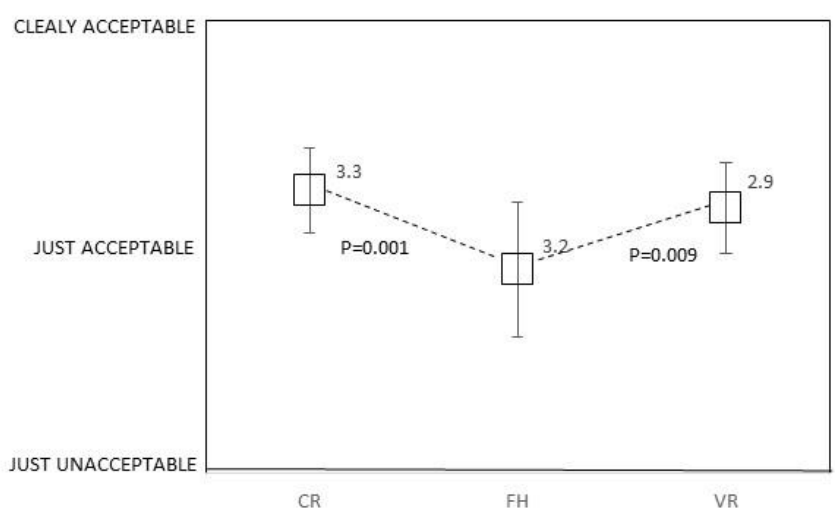

Figure 8 . The mean values of thermal acceptability with $95 \%$ confidence interval bar in different heating system 


\section{ACCEPTED MANUSCRIPT}

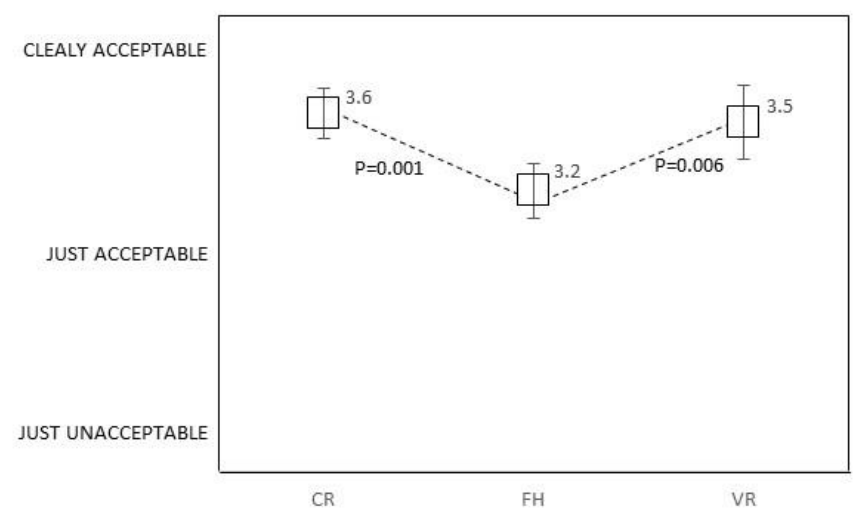

Figure 9. The mean values of draft acceptability with $95 \%$ confidence interval bar in different heating system 


\section{ACCEPTED MANUSCRIPT}
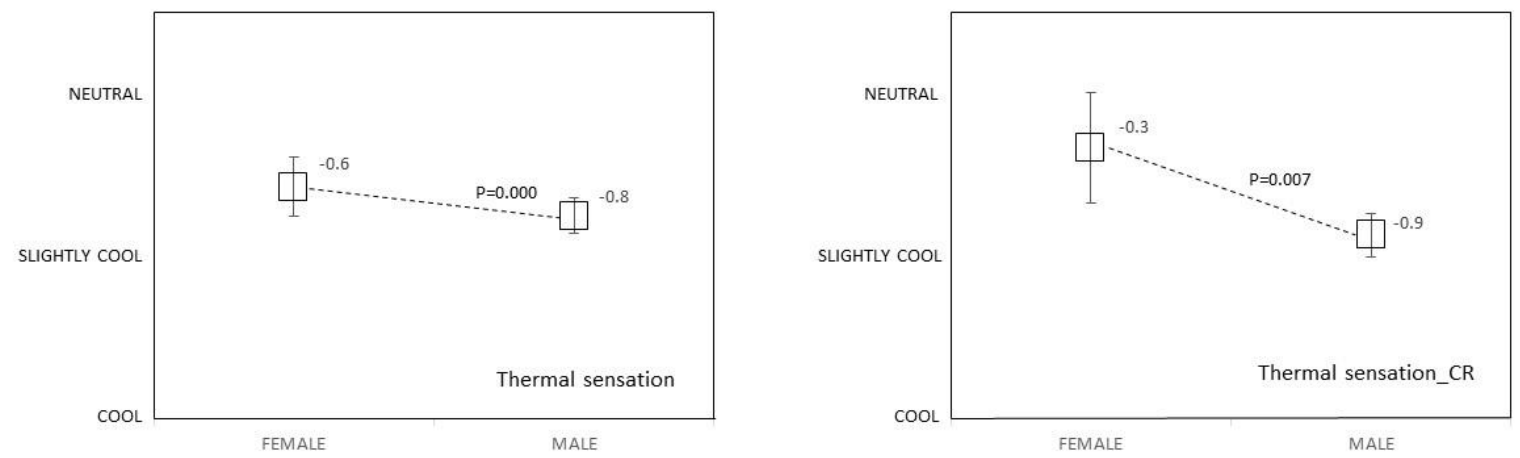

Figure 10. The mean values of thermal sensation with $95 \%$ confidence interval bar in different gender group 


\section{ACCEPTED MANUSCRIPT}
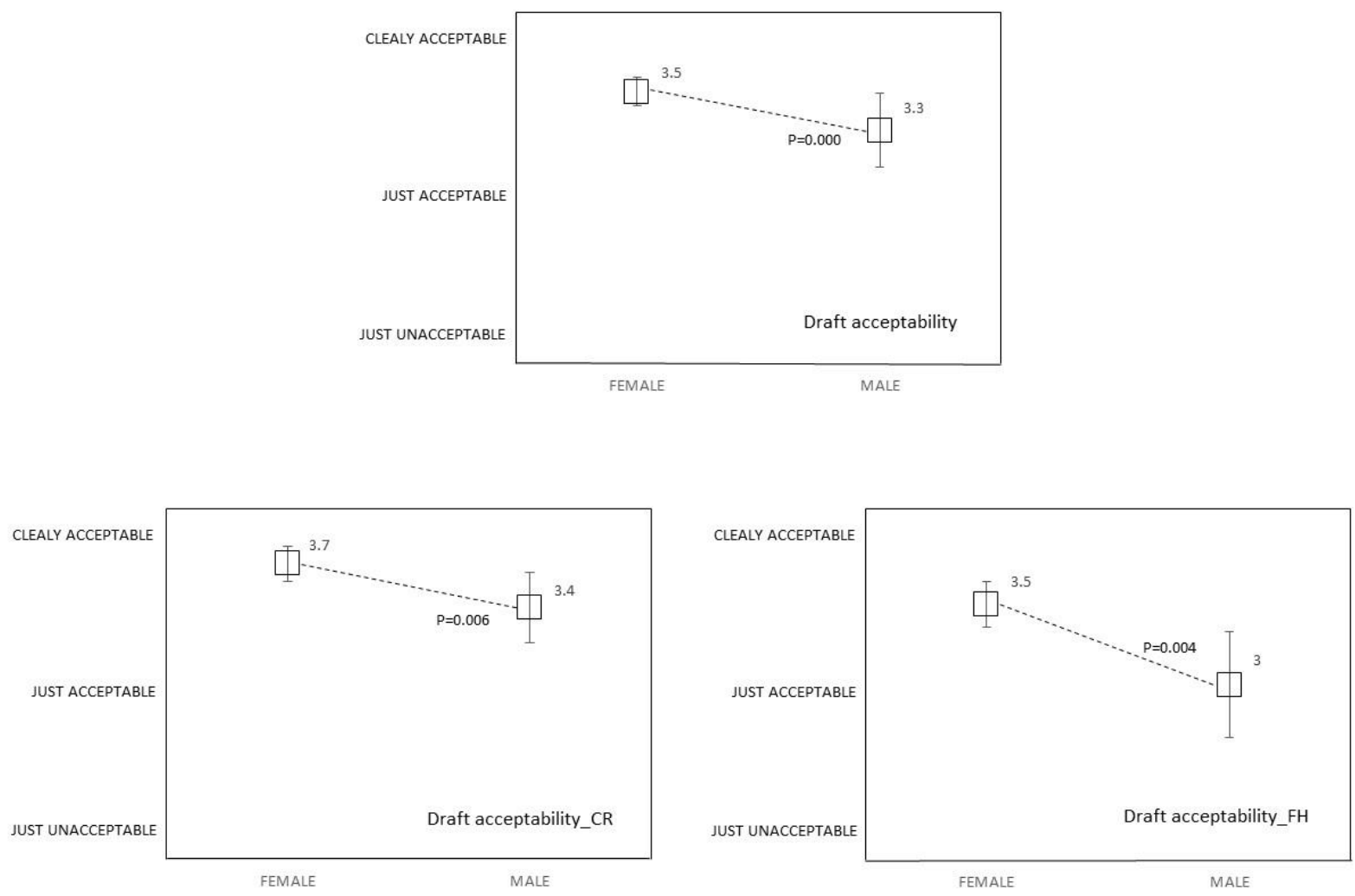

Figure 11. The mean values of draft acceptability with $95 \%$ confidence interval bar in different gender group 


\section{ACCEPTED MANUSCRIPT}

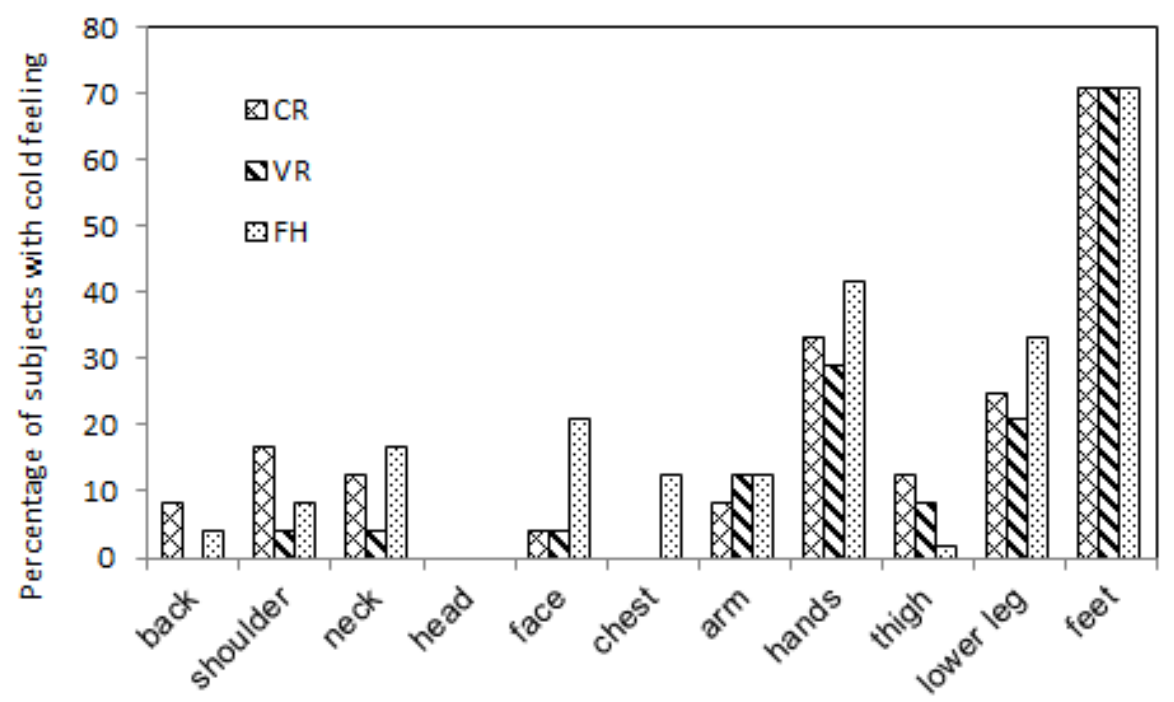

Figure 12. Cold thermal perception on partial body segments 